\title{
КОНЦЕПЦИЯ СОЦИАЛЬНОЙ ОТВЕТСТВЕННОСТИ БИЗНЕСА
}

\author{
(c) 2021 Петрова О.А. \\ старший преподаватель Департамента бизнес-аналитики \\ Финансовый университет при Правительстве Российской Федерации, Россия, Москва \\ E-mail: olga1717@bk.ru
}

Внедрение корпоративной социальной ответственности обусловлено, в первую очередь, тем, что компании осознают свои обязательства перед обществом. Все чаще в современном мире компании стремятся к реализации своей деятельности с учетом социальных задач и проблем, стоящих перед обществом. Компании, задумывающиеся о последствиях своей деятельности, своим стратегическим приоритетом делают КСО (корпоративную социальную ответственность).

Ключевые слова: учет, анализ, аудит, налогообложение, регламент, национальный уровень

Первопроходцами в КСО, а также людьми, впервые открыто заговорившими о КСО, были Д.Своуп, президент компании General Electric, и президент компании American Telephone and Telegraph Company - У.Джиффорд. Идея социальной ответственности постепенно распространялась по всему миру, и многие компании взяли ее «на вооружение». Была создана концепция социальной корпоративной ответственности.

В наши дни компании являются полноценными корпоративными гражданами, имеющими влияние на социальную, экономическую, политическую обстановку. В этих условиях они не могут допустить ухудшения своего образа в глазах потребителей и инвесторов в силу своего халатного отношения к той среде, в которой они ведут свой бизнес.

Объектом анализа в данной работе является политика социальной ответственности бизнеса, предметом - особенности концепции КСО и ее использование в рамках компании. Цель исследования - определение влияния КСО на бизнесактивность компаний. Для достижения поставленной цели будут изучены:

- понятие, составные части и особенности корпоративной социальной ответственности;

- необходимость и выгоды внедрения КСО

- опыт передовых международных компаний по реализации КСО.

В соответствии с ISO 26000:2010 «Руководство по социальной ответственности», корпо- ративная социальная ответственность представляет собой ответственность корпорации за влияние ее деятельности и отдельных решений на общество и окружающую среду посредством этичного и правомерного поведения, содействующего развитию и реализации интересов стейкхолдеров *. Применение КСО позволяет компании пользоваться некоторыми преимуществами, среди которых повышение репутации, рост доверия инвесторов и стейкхолдеров, повышение лояльности сотрудников, улучшение организационной структуры.

Стандарт ISO 26000:2010 раскрывает 7 принципов, которые должны лечь в основу деятельности и управленческих решений организации:

- принцип подотчетности говорит о том, что компания несет ответственность за воздействие на общество и окружающую среду;

- принцип прозрачности гласит, что решения компании, потенциально имеющие влияние на общество, должны быть прозрачны и понятны;

- принцип этического поведения;

- принцип уважения интересов заинтересованных сторон;

- принцип уважения права, международных норм и прав человека.

Основные объекты, на которые ориентирован стандарт, включают организационную структуру, права человека, труд, окружающая среда и экология, практика ведения честной

\footnotetext{
* Колбасенко О.Е.Система корпоративной социальной ответственности компании на основе стандартов ISO 26000:2010 «Руководство по социальной ответственности» // Современный взгляд на проблемы качества и управления конкурентноспособностью в условиях внешних вызовов. Материалы международной (очно-заочной) научно-практической конференции, 2015, с. 110-114.
} 
и этичной деятельности, отношения с потребителями, вовлечение в проблемы общества“. ISO 26000:2010 отмечает всеобъемлющие проблемы, которые касаются указанных объектов, и предлагает пути решения. Например, вопросы труда включают в себя трудоустройство, законные права и обязанности работника и работодателя, дискриминация при устройстве на работу, условия и безопасность труда, развитие и обучение персонала. В связи с этим работодатель должен предоставлять должные условия труда, обеспечивать защиту персональных данных сотрудников, соблюдать их права, развивать социальную политику, направленную на сотрудников, создавать здоровую рабочую атмосферу и прочее.

Стандарт также предусматривает и конкретные способы воздействия на устойчивое развитие общества - конкретные шаги по реализации КСО. К таким методам относятся инвестиционные решения, ориентированные на решение общественных проблем, распространение знаний и информации, участие в совместных проектах (с общественными организациями, фондами и т.п.), использование связей со СМИ для распространения лучших практик и прочее. Стоит отметить, что ICO 26000:2010 является стандартом, а не требованием, и поэтому решение о его внедрении принимает только руководство компании.

Концепция социальной ответственности бизнеса включает в себя следующие компоненты:

- Корпоративный альтруизм. Корпорации - существенный общественный институт, который оказывает воздействие на все общество в целом. Компании несут равную с государством ответственность за благосостояние государства.

- Разумный эгоизм. Никакая коммерческая организация не может влиять на благосостояние общества, поскольку не обладает законодательной властью. Концепция сводится к тому, что предприятия могут способствовать решению некоторых социальных проблем посредством должной налоговой дисциплины, прозрачного ведения своей деятельности и заботы о сотрудниках.

- Корпоративный эгоизм. Основная цель предпринимательской деятельности - получение прибыли, поэтому забота об общественных интересах рассматривается как ненужные материальные затраты.

Социальная ответственность бизнеса подразделяется на две категории: внутренняя и внешняя. К внутренней относятся стабильность оплаты труда, обеспечение безопасных условий труда, медицинское и социальное страхование, развитие персонала, повышение квалификации. К внешней - охрана окружающей среды, корпоративная благотворительность, спонсорство, волонтерство. Результатами внедрения КСО служат следующие преимущества для бизнеса: рост производства, улучшение имиджа компании, повышение узнаваемости, формирование корпоративной уникальности, интенсификация партнерских отношений, государственная поддержка ${ }^{* * *}$.

КСО имеет многоуровневую структуру, которая схематично изображена на рисунке 1.

*International standard ISO 26000:2010 “Guidance on social responsibility”, 2010.

** Петров А. М. Современные концепции бухгалтерского учета и отчетности: учебник / А. М.Петров. - М.: Вузовский учебник: ИНФРА-М, 2018.

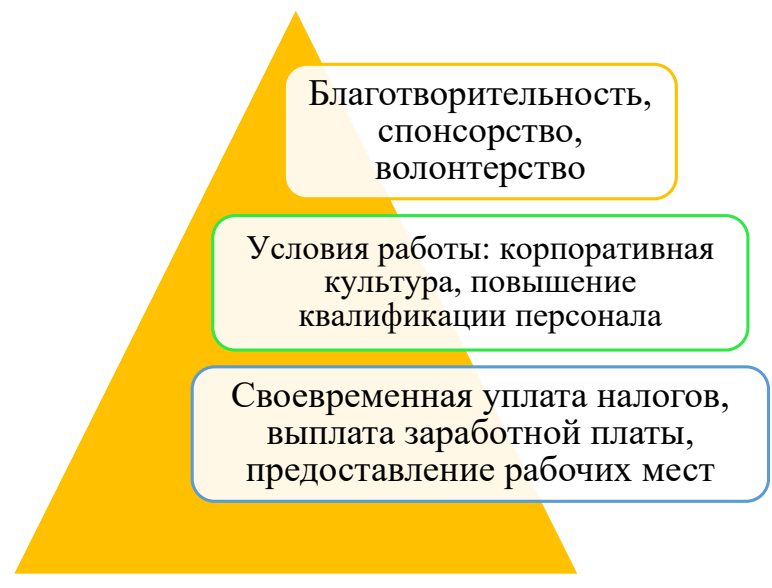

Рuс. 1. Пирамида корпоративной социальной ответственности 
Поднимаясь на ступень выше, компания должна обеспечивать выполнение социальных обязательств на нижестоящем уровне.

Благотворительность может иметь различные формы. Во-первых, это денежные и материальные пожертвования, формирование специальных фондов поддержки, выплата стипендий и пенсий. С другой стороны, благотворительность может рассматриваться как волонтерство, когда сотрудники и менеджмент компании вкладывают свое личное время для решения социальных, экологических, гражданских проблем. Социальная благотворительность в форме волонтерства в России присутствует, однако чаще всего на уровне начальных позиций и молодежи. Однако топ-менеджмент в таких программах почти не принимает участие. Тем не менее, как показывает опыт зарубежных стран, если первые лица в это не вовлечены, то срабатывает вертикальный паттерн, и эффект от волонтерства не наблюдается *.

По мнению экспертов, корпоративная благотворительность должна превратиться в социальное инвестирование, то есть компания должна понимать, в какой проект и в какой временной отрезок лучше вложиться, чтобы получить отдачу. Под отдачей подразумевается не денежный капитал, а социальный, а также другие преимущества, описанные выше. Кроме того, менеджменту компании необходимо осознавать, что наиболее эффективно можно помочь в той области и с помощью таких средств, в которых данное предприятие имеет достаточную экспертизу. Так, стратегия благотворительности должна сочетаться с бизнес-стратегией. Важный критерий успешности благотворительного (социальноинвестиционного) проекта - партнерство. Цели, задачи, средства реализации программы, выгоды и преимущества должны разделяться несколькими партнерами-участниками, чтобы достичь наибольшего результата. Кроме того, компании смогут укрепить деловые связи и, инвестировав свои ресурсы, получить новые. Каждой компании, участвующей в корпоративной благотворительности, необходимо развивать профессиональные компетенции сотрудников, которые занимаются КСО. Они должны понимать, какую отдачу может принести тот или иной проект, а также вести постоянный диалог с представителями различных сообществ, чтобы наиболее полно понять потребности общества и их удовлетворить **.

КСО имеет место тогда, когда компания признает собственную ответственность за принятые и реализованные решения и свои действия, которые так или иначе оказывают влияние на общество и окружающую среду.

Социальная ответственность начинается с отношения собственников и менеджмента корпорации, в первую очередь, к ее сотрудникам и условиям их труда. На этом этапе важно обеспечить периодичность и гарантированность выплаты заработной платы, безопасности труда и достойных условий работы. Когда компания сможет обеспечить такие условия своим сотрудникам, она должна задуматься о формировании корпоративной культуры, которая бы объединила работников и менеджеров на достижение цели. Такая цель обычно заложена в миссии компании, разработка которой также является частью создания корпоративной культуры. Многие развитые компании ежегодно представляют публике отчет о корпоративной ответственности, в котором указывают достижения и мероприятия, приближающие компанию к идеалу «корпоративного гражданина».

После внедрения эффективной социальной политики, направленной «внутрь» компании, как правило, она начинает разрабатывать политику внешней корпоративной ответственности. В нее входят спонсорство, благотворительность, волонтерство, социальное инвестирование. Основная цель подобных мероприятий - улучшение социальной среды и вклад в социальное окружение компании, а также создание имиджа социально ориентированной и ответственной компании.

Россия прошла собственный путь развития КСО от советского государственного патронажа, перехода к рыночным отношениям, приватизации до осознания необходимости частных инвестиций в социальную сферу, заимствования опыта развитых стран. Многие российские компании все еще недостаточно инвестируют ресурсы в КСО, однако существует очевидная тенденция развития КСО в России.

\footnotetext{
* Бизнес - корпоративный гражданин (Наталья Поппель-начальник управления по КСО и бренду «Северстали») // Ведомости. Форум. 23.04.2018, С. 13)

** 10 критериев на пути к идеальному (Ирина Ефремова-Гарт) // Ведомости. Форум. 23.04.2018, С. 9.
} 


\section{Библиографический список}

1. Закон Пермской области от 11.10.2004 № $1622-329$ «О социальном партнерстве в Пермском крае» (с изм. от 10.03.2017)

2. Перегудов С.П., Семененко И. С. Корпоративное гражданство: концепции, мировая практика и российские реалии. - М.: Прогресс-Традиция, 2008.

3. Петров А.М. Современные концепции бухгалтерского учета и отчетности: учебник / А. М.Петров. - М.: Вузовский учебник: ИНФРА-М, 2018.

4. Бизнес - корпоративный гражданин (Наталья Поппель-начальник управления по КСО и бренду «Северстали») // Ведомости. Форум. 23.04.2018, С. 13)

5. Бытдаева М.М., Абдокова Л. З. Социальная и духовная ответственность как составляющие корпоративной социальной ответственности в бизнесе // Научные исследования современных ученых, 2017, с. 140-142.

6. Колбасенко O. Е. Система корпоративной социальной ответственности компании на основе стандартов ISO 26000:2010 «Руководство по социальной ответственности» // Современный взгляд на проблемы качества и управления конкурентноспособностью в условиях внешних вызовов. Материалы международной (очно-заочной) научно-практической конференции, 2015, с. 110-114.

7. Федык Л.А. Внедрение принципов и критериев КСО и добросовестных практик соответствия // Компетентность, № 7(128), 2015, с. 33-36.

8. 10 критериев на пути к идеальному (Ирина Ефремова-Гарт) // Ведомости. Форум. 23.04.2018, С. 9.

9. International standard ISO 26000:2010 “Guidance on social responsibility”, 2010.

10. ЕY- отчет о корпоративной ответственности [электронный ресурc] -https://www.ey.com/ru/ru/about-us/ corporate-responsibility/ey-russia-cr-report-2017. Дата обращения - 28.03.2018. 